\title{
Communities of free living and plant parasitic nematodes in hop gardens in Slovakia
}

\author{
M. LIŠKOVÁ, M. RENČO \\ Parasitological Institute of the Slovak Academy of Sciences, Hlinkova 3, 04001 Košice, Slovak Republic, \\ E-mail: liskova@saske.sk; renco@saske.sk
}

\begin{abstract}
Summary
A total of 61 nematode species belonging into 48 genera was identified in soil of nine localities of hop gardens in Slovakia. From free living soil nematodes the most abundant were the genus Rhabditis - eudominant taxon, species Aphelenchus avenae - dominant taxon, the species Cephalobus persegnis, Chiloplacus propinquus, Aglenchus agricola, Nothotylenchus acris, Aporcelaimellus obtusicaudatus and genus Eudorylaimus were subdominant taxa. Only ten species of plant parasitic nematodes were observed Ditylenchus dipsaci, Bitylenchus dubius, Merlinius brevidens, Rotylenchus robustus, Helicotylenchus canadensis, H. digonicus, Pratylenchus penetrans, P. pratensis, Heterodera humuli, and Paratylenchus bukowinensis. Bitylenchus dubius and Merlinius brevidens belonged to dominant taxa, the species Heterodera humuli and Helicotylenchus digonicus to subdominant taxa. The occurrence of Heterodera humuli cysts was recorded at all localities studied, and the occurrence of $H$. humuli larvae in soil during autumn indicates that possibly more than one generation of the parasite have developed within one vegetation period. The proportion of individual trophic groups in nematode communities of hop gardens was characterised by the prevalence of bacterial feeders followed by plant parasites. The ecological characteristics used for ecological evaluation, especially Maturity Index and Plant Parasitic Index/ Maturity Index, indicate a more disturbed environment. Although hop is a perennial plant, the structure and ecology of its nematode communities is more similar to the agricultural ecosystems with a higher level of agricultural practices.
\end{abstract}

Key words: nematode communities; hop gardens; Slovakia

\section{Introduction}

The wild hop, Humulus lupulus L., can be found freely in nature; commercial hop cultivars used for beer production are grown in suitable climatic and soil conditions throughout the world. The first records of nematodes in soil of hop fields were associated with the occurrence of Heterodera humuli in Germany Voigt (1894) and, subsequently, in England (Percival, 1895). To date, research on nematodes linked with hops had focused mainly on this species considered to be the dominant parasite of hop. Previous investigations studied the geographical distribution of $H$. humuli e.g. in the Czech Republic (Šály \& Křřž, 1961), in Switzerland (Hogger, 1988), in Spain Lopez - Robles (1995), in England (Mende \& McNamara (1995a), in Germany (Eppler, 1999), explored the biology and a life cycle of H. humuli (Mende \& McNamara (1995a,b), pathological effect of $H$. humuli on hop plants connected with different varieties (Mende \& Mc. Namara, 1995b; Hafez et al., 1999), and nematodes as vectors of plant viruses by e.g. Valdez et al. (1974) and Barbez (1982). The other nematodes of the rhizosphere of hop gardens were investigated by Malan et al. (1991), Eppler (1999), and Hay and Pethybridge (2003) and others.

In spite of the substantial investigation of communities of free living and plant parasitic nematodes of various agroecosystems and natural ecosystems in Slovakia, no data from hop gardens are available - with the exception of the reports on the occurrence of $H$. humuli in Slovakia by Šály (1983), but with no closer reference to the habitat. Recently, Sturhan and Lišková (2004) observed H. humuli on a grassy slope at the edge of a forest with the occurrence of Urtica species, known as the host of this nematode species. The objective of the presented work was to determine the structure of nematode communities in specific agroecosystem of hop gardens in Slovakia, focusing on the occurrence of $H$. humuli.

\section{Materials and Methods}

The first recorded hop gardens in Slovakia were set up in 
1920. In 2001, their area covered 1210 ha (Sasin, 2002). However, hop production during the last five years has been dramatically reduced, and at present, hop gardens cover only 350 ha, concentrated at 13 localities in West Slovakia (Fig. 1). Research on nematode communities has been carried out at 9 localities.

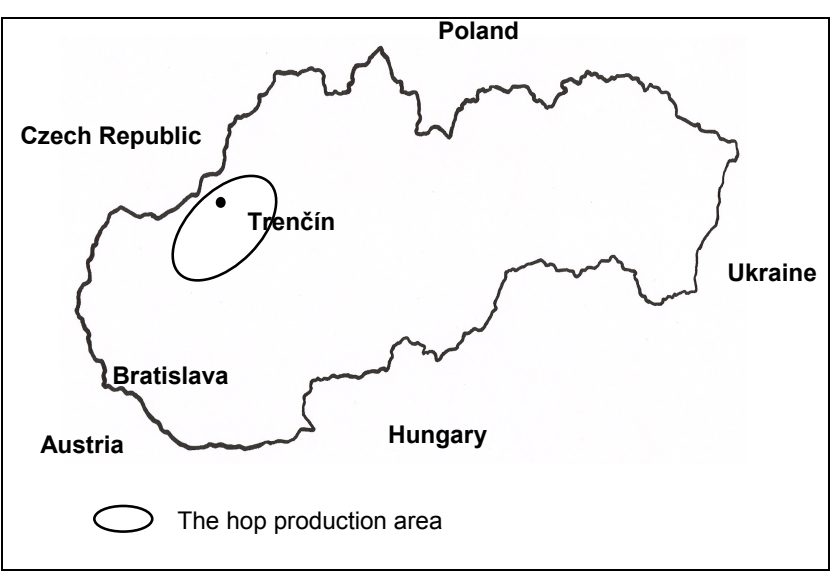

Fig. 1. The hop production area in the Slovak Republic
Climatic and soil characteristics of areas with hop gardens in Slovakia

All nine hop gardens studied are situated in orographic units Trnavská and Nitrianska pahorkatina (upland) and Považské podolie (vale), in warm areas with temperate and moderately humid winters, fog- and wind-free areas, with deep, permeable, loamy, clay loamy or loamy sandy soils, soil type Orthic Luvisol or Eutric Fluvisol with $\mathrm{pH} 6.5$ 7.5 , the level of $\mathrm{pH}$ being maintained by regular liming $\left(20 \mathrm{t} \mathrm{CaCO}_{3} / \mathrm{ha}\right)$ every four years. Hop garden soils are manured every two years $(50-70 \mathrm{t}$ of cattle manure/ha) and fertilised regulary each year - with fertilizer being applied directly to the soil or onto the leaves during vegetation. The investigated localities are at the altitude of $170-210$ $\mathrm{m}$ a.s.l., characterised by annual isotherms of $8.5-9.5^{\circ} \mathrm{C}$, annual rainfalls of $610-680 \mathrm{~mm}$, during the vegetation period with temperatures of $15.5-16.0^{\circ} \mathrm{C}$ and with rainfalls of $350-370 \mathrm{~mm}$.

The average soil samples were collected from the rhizosphere of ten hop plants from each locality, from the depth of $20-40 \mathrm{~cm}$ in July and October 2004. Two sampling dates were used in order to obtain more records of species

Table 1. Specific structure of nematode communities in hop gardens of the Slovak Republic, mean value of taxon abundance in $500 \mathrm{~g}$ of soil, dominance and frequency

\begin{tabular}{|c|c|c|c|}
\hline Nematode species & $\begin{array}{c}\text { Mean value } \\
X \pm S . D\end{array}$ & $\mathrm{D} \%$ & $\mathrm{~F} \%$ \\
\hline \multicolumn{4}{|l|}{ Monhysterida } \\
\hline Eumonhystera filiformis (Bastian, 1965) & $10.2 \pm 0.6$ & 0.04 & 22.2 \\
\hline \multicolumn{4}{|l|}{ Araeolaimida } \\
\hline Anaplectus granulosus (Bastian, 1865) & $0.1 \pm 0.5$ & 0.02 & 11.1 \\
\hline Plectus acuminatus Bastian, 1865 & $1.9 \pm 3.6$ & 0.26 & 44.4 \\
\hline Plectus parietinus Bastian, 1865 & $1.5 \pm 2.9$ & 0.29 & 33.3 \\
\hline Plectus parvus Bastian, 1865 & $0.4 \pm 1.4$ & 0.08 & 22.2 \\
\hline Plectus submersus Hirschmann, 1952 & $0.4 \pm 1.6$ & 0.07 & 11.1 \\
\hline \multicolumn{4}{|l|}{ Rhabditida } \\
\hline Acrobeloides nanus de Man, 1880 & $7.4 \pm 6.8$ & 1.38 & 88.9 \\
\hline Cephalobus persegnis Bastian, 1865 & $18.1 \pm 11.1$ & 3.34 & 100.0 \\
\hline Cephalobus parvus Thorne, 1937 & $1.4 \pm 3.0$ & 0.20 & 22.2 \\
\hline \multicolumn{4}{|l|}{ et Roguska-Wasilewska, 1963) } \\
\hline Eucephalobus oxyuroides (de Man, 1876) & $8.2 \pm 8.3$ & 1.51 & 100.0 \\
\hline Eucephalobus striatus (Bastian, 1865) & $9.5 \pm 8.4$ & 1.75 & 100.0 \\
\hline Acrobeles ciliatus Linstow, 1877 & $1.9 \pm 4.6$ & 0.35 & 44.4 \\
\hline Acrolobus emarginatus (de Man, 1880) & $0.8 \pm 2.6$ & 0.15 & 22.2 \\
\hline Chiloplacus propinquus (de Man, 1921) & $20.1 \pm 21.5$ & 3.71 & 77.8 \\
\hline Chiloplacus symmetricus (Thorne, 1925) & $7.3 \pm 13.0$ & 1.35 & 66.7 \\
\hline Panagrolaimus rigidus (Schneider, 1866) & $8.5 \pm 9.0$ & 1.57 & 100.0 \\
\hline Rhabditis juvs. & $131.2 \pm 206.3$ & 24.21 & 100.0 \\
\hline Steinernema juvs. & $5.9 \pm 9.0$ & 1.10 & 77.8 \\
\hline \multicolumn{4}{|l|}{ Aphelenchida } \\
\hline Aphelenchus avenae Bastian, 1865 & $33.4 \pm 27.3$ & 6.17 & 100.0 \\
\hline Paraphelenchus pseudoparietinus Micoletzky, 1922 & $0.7 \pm 1.8$ & 0.13 & 33.3 \\
\hline Aphelenchoides composticola Franklin, 1957 & $0.6 \pm 2.6$ & 0.11 & 11.1 \\
\hline Aphelenchoides parietinus (Bastian, 1865) & $8.0 \pm 5.7$ & 1.49 & 100.0 \\
\hline Aphelenchoides saprophilus Franklin, 1957 & $1.1 \pm 1.8$ & 0.22 & 44.4 \\
\hline Seinura celeris Hechler in Hechler et Taylor, 1965 & $1.1 \pm 3.2$ & 0.08 & 11.1 \\
\hline
\end{tabular}




\begin{tabular}{|c|c|c|c|}
\hline Seinura oxyura (Paesler, 1957) & $8.0 \pm 13.5$ & 1.49 & 88.9 \\
\hline \multicolumn{4}{|l|}{ Tylenchida } \\
\hline Psilenchus hilarulus de Man, 1921 & $1.2 \pm 2.7$ & 0.11 & 44.4 \\
\hline Basiria gracilis (Thorne, 1949) & $3.5 \pm 6.9$ & 0.65 & 66.7 \\
\hline Boleodorus thylactus (Thorne, 1941) & $1.4 \pm 1.8$ & 0.20 & 88.9 \\
\hline Tylenchus davainei Bastian, 1865 & $1.5 \pm 3.3$ & 0.29 & 55.6 \\
\hline Malenchus bryophilus (Steiner, 1914) & $9.4 \pm 9.9$ & 1.73 & 100.0 \\
\hline Malenchus exiguus (Massey, 1969) & $2.7 \pm 5.6$ & 0.50 & 44.4 \\
\hline Aglenchus agricola (de Man, 1884) & $16.8 \pm 16.7$ & 3.10 & 100.0 \\
\hline Ditylenchus dipsaci (Kühn, 1857) & $0.2 \pm 0.5$ & 0.04 & 22.2 \\
\hline Nothotylenchus acris Thorne, 1941 & $26.4 \pm 35.2$ & 4.67 & 100.0 \\
\hline Bitylenchus dubius (Bütschli, 1873) & $38.9 \pm 42.0$ & 7.17 & 88.9 \\
\hline Merlinius brevidens Siddiqi, 1970 & $51.9 \pm 77.3$ & 9.57 & 88.9 \\
\hline Rotylenchus robustus (de Man, 1876) & $0.3 \pm 1.2$ & 0.05 & 11.1 \\
\hline Helicotylenchus canadensis Waseem, 1961 & $1.2 \pm 3.6$ & 0.23 & 22.2 \\
\hline $\begin{array}{l}\text { Helicotylenchus digonicus Perry in Perry } \\
\text { et Darling \& Thorne, } 1959\end{array}$ & $11.3 \pm 28.7$ & 2.08 & 77.8 \\
\hline Pratylenchus penetrans (Cobb, 1917) & $1.0 \pm 2.3$ & 0.18 & 55.6 \\
\hline \multicolumn{4}{|l|}{ Filipjev et Schuurmans Stekhoven, 1941} \\
\hline Pratylenchus pratensis (de Man, 1880) & $0.7 \pm 1.44$ & 0.13 & 33.3 \\
\hline Heterodera humuli Filipjev, 1934 (juvs. + males) & $18.7 \pm 22.1$ & 3.44 & 88.9 \\
\hline Paratylenchus bukowinensis Micoletzky, 1922 & $5.7 \pm 10.6$ & 1.05 & 88.9 \\
\hline \multicolumn{4}{|l|}{ Enoplida } \\
\hline Prismatolaimus intermedius (Bütschli, 1873) & $0.2 \pm 0.9$ & 0.04 & 11.1 \\
\hline Amphidelus coronatus Andrássy, 1957 & $0.1 \pm 0.5$ & 0.02 & 11.1 \\
\hline Aulolaimus juvs. & $0.2 \pm 0.7$ & 0.03 & 11.1 \\
\hline \multicolumn{4}{|l|}{ Alaimida } \\
\hline Alaimus primitivus de Man, 1880 & $1.7 \pm 1.6$ & 0.32 & 100.0 \\
\hline \multicolumn{4}{|l|}{ Mononchida } \\
\hline Clarkus papillatus (Bastian, 1865) & $1.9 \pm 4.5$ & 0.36 & 44.4 \\
\hline Coomansus parvus (de Man, 1880) & $0.4 \pm 0.8$ & 0.08 & 55.6 \\
\hline Mononchus juvs. & $2.0 \pm 3.6$ & 0.26 & 55.6 \\
\hline Mylonchulus brachyuris (Bütschli, 1873) & $2.1 \pm 3.7$ & 0.39 & 55.6 \\
\hline Mylonchulus micrurus (Cobb, 1917) & $0.2 \pm 0.9$ & 0.04 & 11.1 \\
\hline \multicolumn{4}{|l|}{ Andrássy, 1958} \\
\hline \multicolumn{4}{|l|}{ Dorylaimida } \\
\hline Mesodorylaimus bastiani (Bütschli, 1873) & $1.8 \pm 3.2$ & 0.18 & 22.2 \\
\hline Aporcelaimellus obtusicaudatus (Bastian, 1865) & $20.4 \pm 22.7$ & 3.71 & 88.9 \\
\hline Eudorylaimus leucarti (Bütschli, 1973) & $0.3 \pm 0.9$ & 0.05 & 22.2 \\
\hline Eudorylaimus monohystera de Man, 1880 & $3.8 \pm 7.1$ & 1.00 & 44.4 \\
\hline Eudorylaimus opistohystera (Altherr, 1953) & $4.1 \pm 10.1$ & 0.61 & 11.1 \\
\hline Eudorylaimus vulvostriatus (Stefanski, 1924) & $1.2 \pm 2.9$ & 0.23 & 22.2 \\
\hline Eudorylaimus juvs. & $25.8 \pm 16.0$ & 4.76 & 100.0 \\
\hline Microdorylaimus parvus (de Man, 1880) & $0.3 \pm 1.2$ & 0.05 & 11.1 \\
\hline Longidorella microdorus (de Man, 1880) & $0.3 \pm 1.4$ & 0.06 & 11.1 \\
\hline Axonchium juvs. & $0.3 \pm 0.9$ & 0.05 & 22.2 \\
\hline Oxydirus oxycephalus (de Man, 1885) & $0.3 \pm 0.7$ & 0.05 & 33.3 \\
\hline Dorylaimoides micoletzkyi (de Man, 1921) & $2.8 \pm 4.9$ & 0.52 & 77.8 \\
\hline Paravulvus hartingii (de Man, 1880) & $1.3 \pm 3.9$ & 0.19 & 22.2 \\
\hline \multicolumn{4}{|l|}{ Triplonchida } \\
\hline Diphtherophora communis de Man, 1880 & $0.5 \pm 1.4$ & 0.05 & 22.2 \\
\hline
\end{tabular}

diversity of nematode communities. Nematodes were isolated from $500 \mathrm{~g}$ of mixed soil by using a flotation-sieving method (Cobb, 1918), fixed in FAA (80 parts distilled water, 60 parts $96 \%$ ethanol, 2.4 parts formalin, 1.6 parts acetic acid) (Johansen, 1940) and determined microscopically in permanent glycerine slides. From the soil 82 samples collected in October, the cysts of Heterodera humuli were isolated by using the flotation method of Sabová and Valocká, (1980).

The list of identified species, their mean abundance from all nine localities investigated (X \pm S.D), dominance (D \%) and frequency of the occurrence (F \%) is given in Table 1. 
The indices used for ecological evaluation of nematode communities are given in Table 2, and they are as follows: number of nematode species, number of nematode genera, Shannon Index of diversity for species (H'spp) and for genera (H'gen) (Shannon \& Weaver, 1949), Maturity Index (MI) for nonparasitic nematodes and Plant Parasitic Index (PPI) for plant parasitic nematodes (Bongers, 1990), PPI/ MI ratio: Proportion of Plant Parasitic Index to Maturity Index (Bongers \& Korthals, 1995), B/F ratio: Proportion of Bacterial Feeders to Fungal Feeders (Wasilewska, 1997). The identified genera were allocated into five trophic groups according to classification of Yeates et al. (1993) bacterial feeders, fungal feeders, plant feeders, omnivores and predators. Besides plant feeders as obligate plant parasites, the other group of root fungal feeders was distinguished as a group which included Tylenchus spp. and related species. In addition to these trophic groups, nematodes Steinernema spp. - insect parasites were observed. mus rigidus, Aphelenchoides parietinus, Seinura oxyura, Malenchus bryophilus, Paratylenchus bukowinensis, Eudorylaimus monohystera and genus Steinernema. The species Cephalobus persegnis, Eucephalobus oxyuroides, E. striatus, Panagrolaimus rigidus, Aphelenchus avenae, Aphelenchoides parietinus, Malenchus bryophilus, Aglenchus agricola, Alaimus primitivus and juveniles of the genus Rhabditis and juveniles of the genus Eudorylaimus were observed at all localities investigated.

Nematode communities of hop gardens in Slovakia are characterised by a low number of plant parasitic species, only ten species ( $16 \%$ from a total number of species) were recorded; Ditylenchus dipsaci, Bitylenchus dubius, Merlinius brevidens, Rotylenchus robustus, Helicotylenchus canadensis, $H$. digonicus, Pratylenchus penetrans, P. pratensis, Heterodera humuli, and Paratylenchus bukowinensis. In spite of the low number of species, the proportion of plant parasitic nematodes within localities was $10-40$

Table 2. Nematode cummunity structure of hop gardens in the Slovak Republic

\begin{tabular}{|c|c|c|c|c|c|c|c|c|c|c|}
\hline \multirow[t]{2}{*}{ Nematodes } & \multicolumn{10}{|c|}{ Localities } \\
\hline & Čachtice & $\begin{array}{c}\text { Hôrka } \\
\text { nad } \\
\text { Váhom }\end{array}$ & Chocholná & Kočovce & Nemšová & Soblahov & $\begin{array}{l}\text { Trenčianske } \\
\text { Stankovce }\end{array}$ & $\begin{array}{l}\text { Trenčianska } \\
\text { Turná }\end{array}$ & Vrbové & $\begin{array}{c}\text { Mean value } \\
x \pm \text { S.D. }\end{array}$ \\
\hline Number of species & 25 & 44 & 24 & 38 & 28 & 31 & 34 & 30 & 26 & $31.1 \pm 6.6$ \\
\hline Number of genera & 25 & 39 & 24 & 32 & 26 & 29 & 28 & 28 & 25 & $28.4 \pm 4.7$ \\
\hline Total abundance & 186 & 692 & 309 & 530 & 1077 & 609 & 571 & 666 & 236 & $507.9 \pm 321.9$ \\
\hline Bacterial feeders $\%$ & 40.3 & 28.1 & 38.0 & 42.3 & 65.0 & 34.4 & 41.1 & 28.4 & 31.1 & $38.7 \pm 11.2$ \\
\hline Fungal feeders $\%$ & 16.1 & 14.3 & 13.7 & 10.7 & 6.3 & 11.3 & 16.4 & 27.6 & 25.4 & $15.8 \pm 6.8$ \\
\hline Root-fungal feeders $\%$ & 4.3 & 4.9 & 15.5 & 7.4 & 6.3 & 9.3 & 6.4 & 4.1 & 1.7 & $6.6 \pm 4.0$ \\
\hline Plant parasitites $\%$ & 10.5 & 39.8 & 19.1 & 30.2 & 15.3 & 27.2 & 14.5 & 29.3 & 19.5 & $22.8 \pm 9.4$ \\
\hline Omnivores \% & 24.2 & 10.5 & 13.2 & 5.7 & 6.5 & 13.4 & 19.1 & 10.1 & 21.6 & $13.8 \pm 6.5$ \\
\hline Predators \% & 3.8 & 0.9 & 0.5 & 1.3 & 0.5 & 3.7 & 1.5 & 0.5 & 0.2 & $1.4 \pm 1.4$ \\
\hline Insect parasites $\%$ & 0.8 & 1.1 & - & 2.5 & 0.5 & 0.7 & 1.0 & - & 0.6 & $0.8 \pm 0.7$ \\
\hline $\mathrm{H}^{\prime} \mathrm{spp}$ & 2.30 & 2.65 & 2.25 & 2.69 & 2.66 & 2.78 & 2.82 & 2.45 & 2.07 & $2.51 \pm 0.26$ \\
\hline $\mathrm{H}^{\prime}$ gen & 2.34 & 2.60 & 2.37 & 2.43 & 1.91 & 2.70 & 2.63 & 2.42 & 2.20 & $2.40 \pm 0.24$ \\
\hline MI & 2.42 & 2.29 & 2.56 & 1.97 & 1.49 & 2.30 & 2.33 & 2.12 & 2.34 & $2.20 \pm 0.31$ \\
\hline PPI & 2.98 & 2.81 & 2.97 & 2.89 & 2.91 & 3.01 & 2.91 & 2.93 & 2.90 & $2.82 \pm 0.43$ \\
\hline $\mathrm{PPI} / \mathrm{MI}$ ratio & 1.23 & 1.22 & 1.16 & 1.46 & 1.95 & 1.30 & 1.24 & 1.38 & 1.25 & $1.35 \pm 0.30$ \\
\hline $\mathrm{B} / \mathrm{F}$ ratio & 2.50 & 1.96 & 2.77 & 3.95 & 10.31 & 3.04 & 2.50 & 1.01 & 1.22 & $3.25 \pm 2.79$ \\
\hline
\end{tabular}

\section{Results}

A total of 61 nematode species from 48 genera were observed in hop gardens in Slovakia. The number of the species varied $(24-44)$, genera $(24-39)$, abundance of nematodes $186-1077$ individuals in $500 \mathrm{~g}$ of soil within investigated localities. The genus Rhabditis is the eudominant taxon, species Aphelenchus avenae, Bitylenchus dubius and Merlinius brevidens are dominant taxa, species Cephalobus persegnis, Chiloplacus propinguus, Aglenchus agricola, Nothotylenchus acris, Helicotylenchus digonicus, Heterodera humuli, Aporcelaimellus obtusicaudatus and genus Eudorylaimus are subdominant taxa, recendent taxa are the species Acrobeloides nanus, Eucephalobus oxyuroides, E. striatus, Chiloplacus symmetricus, Panagrolai-
$\%$, and the species Bitylenchus dubius and Merlinius brevidens belonged to the most frequent and dominant species of all, followed by free living nematodes of the genus Rhabditis. The attention of the investigation was payed to the species Heterodera humuli as well. In soil samples collected in July, males were observed at seven localities, with an abundance of $2-22$ specimens in $500 \mathrm{~g}$ of soil and at one locality, besides males, one juvenile (J2) was recorded as well. In October, juveniles occurred (19- 78 specimens in $500 \mathrm{~g}$ of soil), and hereby the cysts of $H$. humuli at all localities were recovered. The number of cysts varied within localities $(11-33$ cysts in $100 \mathrm{~g}$ of soil). From other plant parasitic species, Helicotylenchus digonicus and Paratylenchus bukowinensis were frequent, but both species with fluctuating low population density 
within localities. The other plant parasitic species occurred more rarely; longidorid and trichodorid nematodes as potential vectors of plant viruses were not recorded at all.

The dominant trophic group in hop gardens was bacterial feeders. The most abundant was the genus Rhabditis followed by the genera Chiloplacus, Cephalobus and Eucephalobus. The proportion of fungal feeders and root fungal feeders varied within localities, most frequent and abundant were the genera Aphelenchus and Nothotylenchus followed by genus Aphelenchoides. From root fungal feeders, most abundant was the genus Aglenchus. Besides bacterial feeders, the plant feeders were a group with the highest proportion of all trophic groups. The most abundant were the genera Merlinius, and Bitylenchus. The proportion of omnivores varied within localities as well and the most frequent and abundant genera were Eudorylaimus and Aporcelaimellus. A very low proportion of predators was ssociated with a very low abundance at all localities studied.

The H'spp mean value indicated a low species diversity in nematode communities within localities. Similarly, H'gen was compounded with the exception of one locality (Nemšová) only, where H'gen was lower. The Maturity Index MI varied within localities and its lowest value at locality Nemšová reflected a very low proportion of taxa with a high c-p value (persisters) - predators and omnivores and a high proportion of taxa with low c-p value (colonizers), mostly bacterial feeders. The PPI value and ratio PPI/MI was relatively balanced within localities. A substantial variation of $\mathrm{B} / \mathrm{F}$ ratio has been recorded within localities. The lower $\mathrm{B} / \mathrm{F}$ ratio value is influenced by the higher proportion of fungal feeders (e.g. localities Trenčianska Turná and Vrbové), the highest BF ratio value e.g at locality Nemšová is inluenced by very high proportion of bacterial feeders in comparison with the other localities.

\section{Discussion}

The communities of free living and plant parasitic nematodes of investigated hop gardens are characterised by a lower number of identified taxa, including a lower number of plant parasitic species (10) in comparison with other ecosystems studied in Slovakia. For instance Sabová and Valocká (1977) identified in cereal fields 30 plant parasitic species, Lišková (1977) in vineyards 21 and Lišková and Čerevková (2005) in natural river banks 41 species of plant parasitic nematodes. Hop gardens were characterised by a fluctuating number of identified taxa as well as by fluctuating total abundance of nematodes within localities. Results of the structure of nematode communities from hop gardens resembled the results from sugar beet fields (Renčo \& Valocká, 2002), where, similarly, such taxa as Cephalobus persegnis, Chiloplacus symmetricus, Rhabditis spp., Aphelenchus avenae, Bitylenchus dubius, Merlinius brevidens, Nothotylenchus acris, Aporcelaimellus obtusecaudatus and Eudorylaimus spp. also belonged to the most abundant and the most frequent nematodes. A considerable dissimilartity between sugar beet fields and hop gardens was in a high population density and frequency of Pratylenchus spp. in soil with sugar beet; in hop gardens these nematodes were very rare. An entirely different structure of nematode communities has been observed in natural ecosystems in Slovakia, e.g. ecosystem of the river banks vegetation (Lišková \& Čerevková, 2005) and natural meadows (Háňel \& Čerevková, 2006) in comparison to hop gardens.

The record of the occurrence of Heterodera humuli from all localities studied is the first report on this species in Slovak hop gardens. From the occurrence of juveniles in October, it is possible to assume the presence of more than one generation of the parasite during a vegetation period. This is in agreement with the assumption of the development of two or three generations of $H$. humuli in England (Mende \& McNamara, 1995a). According to Brown et al. (1993) and Hay and Pethybridge (2003), hop has a solid capacity to tolerate nematode feeding, but research by Mende and McNamara (1995b), Hafez et al. (1999) and by Hay and Pethybridge (2003) has shown that at high population density of $H$. humuli, when infested plants are under stress from drought or from other pathogens, the high population density can adversely affect losses of hop production. In spite of a low number of plant parasitic species observed in Slovakian hop gardens, population density and frequency of the species Bitylenchus dubius and Merlinius brevidens was high nearly at all localities and, together with $H$. humuli, these nematodes can be a potential factor negatively influencing hop growing in Slovakia.

The following order of trophic groups was observed - bacterial feeders $>$ plant feeders $>$ fungal feeders $>$ root fungal feeders $>$ omnivores $>$ predators. The dominant trophic group were bacterial feeders with the exception of one locality Hôrka and Váhom, where plant parasites were dominant. The high proportion of bacterial feeders indicates an increase in microbial activity of soil, first of all an increase in nematodes of the genus Rhabditis, which are able to multiply in a short time when organic matter is added to the soil (Wasilewska, 1997). Hop gardens investigated were regularly manured with high doses of cattle manure (50 - 70t/ha each second year) and fertilised regularly every year. Similarly, the high proportion of bacterial feeders in sugar beet fields observed by Renčo and Valocká (2002) may also be a result of a high cattle manure supply. The second most abundant trophic group were plant parasites, despite the low number of occurring species. The high proportion of plant parasites is symptomatic for agroecosystems growing one specific host plant for more years, e.g., for Ditylenchus dipsaci associated with lucerne (Valocká, 1975), or longidorids with grapevine, fruit, or forest trees (Lišková \& Brown, 2003). A higher proportion of fungal feeders was observed in Trenčianska Turná and Vrbové, where slower decomposting processes in heavier clay-loamy soils can be supposed. The proportion of omnivores fluctuated within localities. After Ferris and Ferris (1974) and Wasilewska (1979) this trophic group is considered to be sensitive to management prac- 
tices, and the relatively high proportion of omnivores at some localities (indicating more stable ecosystem) is in the contrary with high proportion of plant parasites in hop gardens, because plant parasites indicate more disturbed ecosystem. Similarly, a low proportion of predators indicates a disturbed environment (Yeates \& Bird, 1994, Freckman \& Ettema, 1993).

The values of $\mathrm{H}^{\prime}$ spp and $\mathrm{H}^{\prime}$ gen indices, are characterised by a low fluctuation within localities, that suggests similar environmental conditions within localities. The low MI value is a reflection of a high proportion of bacterial feeders with c-p value 1 and 2 and a very low proportion of predators with higher c-p value and a higher MI reflects a less disturbed ecosystem (Freckman \& Ettema, 1993). Therefore, hop fields with MI 1.5 - 2.6 can be considered as a more disturbed ecosystem than e.g. permanent meadows and pastures with MI 3.4, resp. 3.5 (Čerevková, 2006). According to Bongers et al. (1997), the PPI/MI ratio increases gradually from natural undisturbed ecosystems to intensively managed agricultural ecosystems, and in natural habitats, where higher plants make optimal use of nutrient resources, the ratio does not exceed 0.9. Therefore, the PPI/MI ratio with value $>1.20$ at all localities indicates a more disturbed ecosystem influenced by intensive agricultural practices. The $\mathrm{B} / \mathrm{F}$ ratio provides information on the dominant way in which the breakdown of organic matter proceeds, i.e. with the participation of bacteria or fungi (Wasilewska, 1997) and a higher value indicates prevalence of decomposting processes. In hop gardens the $\mathrm{B} / \mathrm{F}$ ratio has a large fluctuation, that considerably depends again on the manure of soil.

This first information about the structure of nematode communities of Slovak hop gardens was based on the current continual investigation of seasonal dynamics of nematodes with particular attention paid to the life cycle and the phytopathological importance of Heterodera humuli. The accumulated knowledge extends the understanding of the interactions within nematode communities and soil biota in this specific agroecosystem.

\section{Acknowledgements}

This study was supported by the VEGA scientific grant agency, Grant No. 2/4176/26 and Slovak Research Development Agency APVT, project No. 51-014604.

\section{References}

BARBEZ, D. (1982): Bestrijding en controle van brandnetelblad bij hop. Agricontact, 118: $1-4$

BONGERS, T. (1990): The maturity index: an ecological measure of environmental disturbance based on nematode species composition. Oecologia, 83: $14-19$

Bongers, T., Korthals, G. (1995): The behavior of maturity index and plant parasite index under enriched conditions. Nematologica, 41: 286

Bongers, T., Van Der Meulen, H., Korthals, G. (1997): Inverse relationships between the nematode matu- rity index and plant parasite index under enriched nutrient conditions. Appl. Soil Ecol., 6: 195 - 199

Brown, D. J. F., Dalmasso, A., Trudgill, D. L. (1993): Nematode Pests of Soft Fruits and Vines. In Evans, K., Trudgill, D.L. \& Webster, J.M. (Eds.): Plant Parasitic Nematodes in Temperate Agriculture. CAB International, Wallingford, $427-462$

CoBB, N. A. (1918): Estimating the nema population of the soil. Agric. Tech. Circ. Bur. Pl. Ind. U.S. Dep. Agric., 1.

ČEREVKOVÁ, A. (2006): Nematode communities in three types of grassland in the Slovak Republic. Helminthologia, 43: $171-176$

EPPler, A. (1999): Die Fauna des Hopfens. Proceedings $51^{\text {st }}$ international symposium on crop protection, Gent, Belgium. Universiteit Gent, 64: 133 - 147

FERRIS, V. R., FERRIS, J. M. (1974): Inter-relationships between nematode and plant communities in agricultural ecosystems. Agroecosystems, 1: 275 - 299

FrecKMAN, D.W., EtTEMA, CH.H. (1993): Assessing nematode communities in agroecosystems of varying human intervention. Agriculture, Ecosystems and Environment, 45: 239 - 261

HÁŇEL, L., ČEREVKOVÁ, A. (2006): Diversity of soil nematodes in meadows of the White Carpathians. Helminthologia, 43: $109-116$

Hafez, S. L., Sundararaj, P., BArbour, J. (1999): Impact of Heterodera humuli on growth and mineral nutrition composition of hops Humulus lupulus cv. Cascade. Intern. J. Nematol., 9: $23-26$

Hay, F., Pethybridge, S. (2003): Plant-Parasitic Nematodes Associated with Hop Production in Tasmania, Australia. J. Phytopathol., 151: $369-375$

HogGer, C. H. (1988): Plant parasitic nematodes in Swiss hop yeards. Hopfenrundschau, 39: 127 - 130

JoHANSEN, D. A. (1940): Plant microtechnique. New York \& London, McGrow Hill Book Co.

LIŠKOVÁ, M. (1977): Helminthocenoses of grapevine in East-slovak vineyard areas. Helmintological Institute of SAS, Košice

LIŠKOVÁ, M., BROWN, D.J.F. (2003): Longidoridae (Nematoda: Dorylaimida) in the Slovak Republic. Helminthologia, 40: 165 - 172

LiŠKOVÁ, M., ČEREVKOVÁ, A. (2005): Nematode communities of river banks and adjacent meadows in the Slovak Republic. Helminthologia, 42: 223 - 232

LOPEZ-RoBles, J. (1995): Distribution of Heterodera humuli in Spain. Nematol. medit., 23: $73-75$

Malan, A. P., Pieterse, W., Britis, G. (1991): Plant-parasitic nematodes associated with hops (Humulus lupulus L.) in South Africa. Phytopathologica, 23: 173 - 175

Mende, N. Von, MCnAmarA, D.G. (1995a): Biology of the hop cyst nematode Heterodera humuli I. Life cycle and survival. Ann. Appl. Biol., 126: $505-516$

Mende, N. Von, Mcnamara, D.G. (1995b): Biology of the hop cyst nematode Heterodera humuli II. Host-parasite relationship of the nematode and its interaction with Verticillium alboatrum. Ann. Appl. Biol., 126: 517 - 526

Percival, J. (1895): An eelworm disease of hops. Nat. 
Sci, 5: $187-197$

RENČO, M., VALOCKÁ, B. (2002): Communities of soil and plant nematodes in sugar beet growing areas of the Slovak Republic. Biologia, Bratislava, 57: 569 - 573

SABOVÁ, M., VALOCKÁ, B. (1977): Free living and plant parasitic nematodes from cereal areas of SSR. Helminthological Institute of SAS, Košice

SABOVÁ, M., VALOCKÁ, B. (1980): Plant parasitic nematodes of cerals in Slovakia. Pol'nohospodárstvo, 26: $278-$ 285

SASIN, A. (2002): Hop production in Slovakia. 2, Slovchmel' Horná Streda, Piešt’any

Shannon, C. E., WeAVER, W. (1949): The Mathematical Theory of Communication. Urbana, University of Illinois Press.

STURHAN, D., LIŠKOVÁ, M. (2004): Cyst nematodes in the Slovak Republic. Helminthologia, 41: 217 - 219

ŠÁLY, A. (1983): Free living nematodes in the Slovak Republic. VEDA, Publishing House of SAS, Bratislava

ŠÁLY, A, KŘíž, J. (1961): Hop cyst nematode - pest of hop. Chmelařství, 34: 43

Valdez, R. B., Mcnamara, D. G., Ormerod, P. J.,
Pitcher, R. S., Tresh, J. M. (1974): Transmission of the hop strain of arabis mosaic virus by Xiphinema diversicaudatum. Ann. Appl. Biol., 76, 113 - 122

VALOCKÁ, B. (1975): Helmintocenoses of alfalfa. Helminthological Institute of SAS, Košice

VoIGT, W. (1894): Neue Varietät des Rübennematoden (Heterodera schachtii) S.B. niederrhein. Ges. Nat. Heilk., 51: $94-97$

WASILEWSKA, L. (1979): The structure and function of soil nematode communities in natural ecosystems and agrocenoses. Pol. ecol. Stud., 5: 97 - 145

WASILEWSKA, L. (1997): Soil invertebrates as bioindicators, with special reference to soil-inhabiting nematodes. Russ. J. Nematol., 5: $113-126$

Yeates, G. W., Bongers, T., De Goede, R. G. M., FreckMAN, D. W., GEORGIEVA, S.S. (1993): Feeding habits in soil nematode families and genera - An outline for soil ecologists. J. Nematol., 25: $315-331$

YeATES, G. W., BIRD, A. F. (1994): Some observation on the influence of agricultural practices on the nematode faunae of some South Australian soils. Fund. Appl. Nematol., 17: $133-145$ 